\title{
Jhadi taal wetland - an abode for wild germplasm of monotypic genus Euryale ferox salisb. In Kishanpur wildlife sanctuary, Terai region, Uttar Pradesh, India.
}

Neelam Gautam* and Vineet Singh

Botanical Survey of India, Central Regional Centre, Allahabad, Uttar Pradesh, India.

Received: February 30, 2017; Accepted: March 21, 2017

\begin{abstract}
Jhadi taal wetland in Kishanpur Wildlife Sanctuary sustains a variety of rare and unique floral and faunal elements in northern terai region of Uttar Pradesh. In the present communication rare population of wild germplasm of economically valuable and monotypic genus Euryale ferox is reported which may play a crucial role in conservation and possibility of diverse gene flow. Its occurrence in the sanctuary also restricts exploitation of this least concern species in naturally protected environment.
\end{abstract}

Key words: Euryale ferox; Jhadi taal; wild germplasm; monotypic

\section{Introduction}

Euryale ferox Salisb. is a monotypic genus with little genetical divergence and also an IUCN red listed species (Zhuang, 2011) belonging to family Nymphaeaceae, sub family -Euryaloideae. Its range of distribution is East Asia-China, Japan, Russian Federation, Bangladesh and Northern India. In spite of being a temperate plant, brought into south by bird dispersal, it has adapted to the tropical climate of India and get distributed in tropical and sub-tropical regions of south east and south east Asia. In our country it is of wild occurrence in eastern part along the Indo Gangetic flood plain, Manipur, Meghalaya and Tripura. It is commonly recognized as Giant water lily, Prickly water lily, Foxnut, yields seeds of Makhana, which is an important revenue source. The plant is over exploited by locals and is frequently cultivated in shallow and stagnant water reservoir for commercial profits in eastern part of India. During course of field exploration tour to Kishanpur Wildlife Sanctuary, a secluded small population of naturally growing wild germplasm of this economically and medicinally significant species was observed in Jhadi taal. The sanctuary is a constituent of the Dudhwa tiger reserve in U.P. and the largest wetland of the sanctuary, Jhadi taal (N 28 21' 58.3" E $80^{\circ} 26^{\prime} 31.1^{\prime \prime}$ altitude $146 \mathrm{~m}$ ) alongwith its enchanting beauty is known to be the lifeline of the many endangered and vulnerable mammals with decreasing population viz. Royal Bengal Tiger (Panthera tigris ssp. tigris), Swamp Deer (Rucervus duvancelii), Hispid Hare (Caprolagus hispidus) etc. Many resident and migratory avian fauna including critically endangered Bengal Florican (Houbaropsis bengalensis) add uniqueness to the taal. By interviewing the locals and forest officials regarding its cultivation in the wetland of the sanctuary there were no record of this since long back. The records of Euryale ferox from the wild vicinity in Uttar Pradesh are inadequate. The sudden existence of it may be due to avian dispersal as the sanctuary sustains many migratory and native bird species as wintering ground. The patch was very luxuriant regardless of very shallow water possibly by virtue of its wild stress resistance genes.

It is a prickly aquatic annual or perennial herb (Fig. $1 \mathrm{~A}$ B) having a short, thick sunken rhizome; leaves about $10-100 \mathrm{~cm}$ across, submerged, grooved, flat, oblong, orbicular in shape, above surface is reddish green while the lower surface is purplish, quilted in texture, spinous on both surface, lower surface of the leaves comprise of obtruding veins surrounded with dense prickles. Petiole long spiny, Flowers purple solitary (Fig.1C), small, epigynous, glabrous inside and prickly outside, sepals spiny, petals seriated, multicarpellary ovary, Fruits spongy, conical with persistent calyx covered with sharp spines (Fig.1D). Fruits contain 20-40 seeds with hard seed coats black in colour. Dehisced nuts are covered with mucilaginous aril.

The stem, young shoot and seeds of this plant are edible and included in many dietary preparations. The seeds are important constituent of many ayurvedic preparations related to sexual dysfunction, vata and pitta, against a number of ailments including respiratory, circulatory, digestive, renal, excretory and reproductive system. It has been used as wild food sources since the period of cultural evolution. The seeds are highly nutritious as it has a high content of essential amino acids, iron, minerals and traces of carotene. Due to high content of vitamins it is also used for treatment of beriberi caused by deficiency of vitamin B (Chaudhuri and Dutta, 2006). Puffed Makhana seeds are delicious and nutritious and can be served as an alternative source of food for future.

\footnotetext{
*Corresponding Author:

Dr. Neelam Gautam,

Scientist- B,

Central Regional Center, Botanical Survey of India,

10, Chatham Line, Allahabad-211002,

Uttar Pradesh, India.

E-mail: neelamsaggy@gmail.com
}

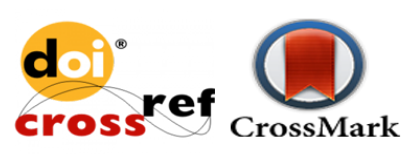



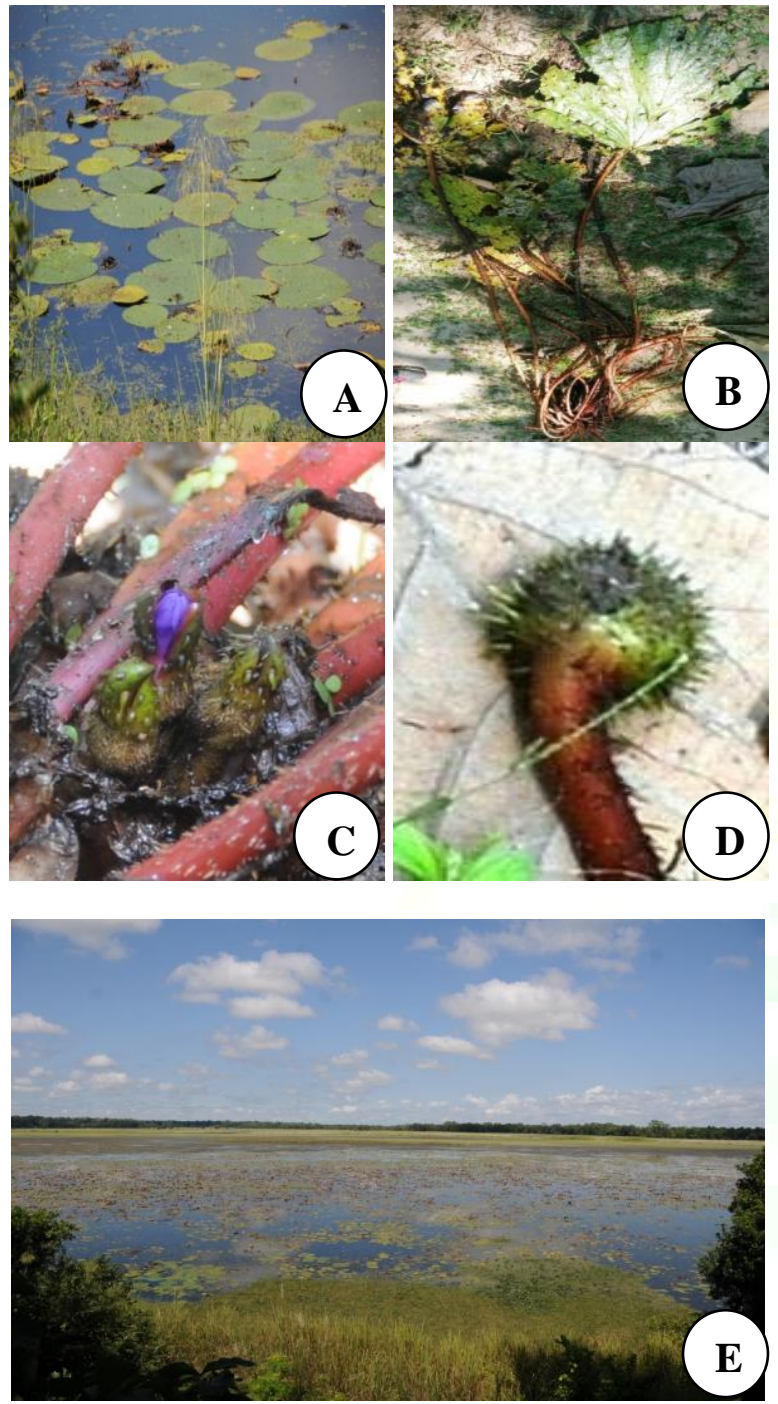

Fig. 1: A-B Habit of Euryale ferox C. Flowers D. An indehiscent spiny fruit E. Panoramic view of Jhadi Taal in KWLS

In Euryale the flowers generally open under water so it is restricted to self-pollination and consequently lack genetic variability which elevates risk of inbreeding depression. For the species which is progressively under threat of over exploitation for revenue generation and wild germplasm are threatened, there is chance of decline and extinction of population. Occurrence of Euryale ferox in Jhadi taal (Fig.1 E), an unscathed wetland plays a crucial role in conservation and restrict exploitation of this least concern species in naturally protected environment. The survey aid in identifying an alternative potential distributional wild habitat for this highly important species which may attribute in establishment of the species in the adjoining region also. Besides this, the translocation of the species in a new habitat may foster better adaptation and flow of novel and varied gene may open way for genetic diversity.

\section{Acknowledgements}

The authors are thankful to the Director, Botanical Survey of India, Kolkata and the Head of office, Central Regional Centre, BSI, Allahabad for facilities and encouragements. The first author is also grateful to the Deputy Director of the Dudhwa Tiger Reserve, Uttar Pradesh for his kind permission for survey and collection of plant specimens during field exploration.

\section{References}

1. Chaudhuri SK \& Dutta C, Impacts of a patent on Euryale ferox on biodiversity at micro level: A case study. Journal of Intellectual Property Rights, 2006, 11: 430-435.

2. Zhuang X, Euryale ferox. The IUCN Red List of Threatened Species 2011: e.T168756A6535154. http://dx.doi.org/10.2305/IUCN. UK.20112.RLTS.T168756A6535154.en. Downloaded on 23 March 2017.

\section{Cite this article as:}

Neelam Gautam and Vineet Singh. Jhadi taal wetland - an abode for wild germplasm of monotypic genus Euryale ferox salisb. In Kishanpur wildlife sanctuary, Terai region, Uttar Pradesh, India. Annals of Plant Sciences 6.04 (2017): 1602-1603.

DOI: http://dx.doi.org/10.21746/aps.2017.04.002

Source of support: Nil.

Conflict of interest: Nil 